\title{
PENGGUNAAN KALIANDRA (Calliandra calothyrsus), Indigofera sp. DAN CAMPURANNYA DALAM RANSUM SEBAGAI PENGGANTI KONSENTRAT TERHADAP PRODUKTIVITAS DOMBA GARUT JANTAN
}

\section{The Use of Calliandra calothyrsus, Indigofera sp. and Its Mix in Diet to Substitute Concentrate on Productivity of Male Garut Sheep}

\author{
Syifa Nurjannah', Budi Ayuningsih², Iman Hernaman², Iin Susilawati² \\ ${ }^{1}$ Major of Animal Husbandry, Faculty of Agriculture, Bandung Raya University \\ ${ }^{2}$ Faculty of Animal Husbandry, Padjadjaran University \\ J1. Banten, No. 11, Kebon Waru, Batununggal, Bandung, Jawa Barat, 40272 \\ Email : syifa.nurjannah21@gmail.com
}

\begin{abstract}
This research aimed to determine the productivity of livestock. Feed availability in the dry season is one of the causes low productivity of livestock. Calliandra calothyrsus (C. calothyrsus) and Indigofera sp. are leguminosae plant that resistant to drought and could produce high productivity. Both can be used as a sustainable animal feed and reduce production costs. The animal used was weaned male sheep. The method used was Completely Randomized Design (CRD), with six treatments (P0:70\% Grass $+30 \%$ Concentrate, P1 : 70\% P. Grass $+15 \%$ Concentrate $+15 \%$ C. calothyrsus, P2 : $70 \%$ Grass $+15 \%$ Concentrate $+15 \%$ Indigofera sp., P3: 70\% Grass $+30 \%$ C. calothyrsus, P4:70\% Grass $+30 \%$ Indigofera sp., P5 : 70\% Grass $+15 \%$ C. calothyrsus $+15 \%$ Indigofera sp.) and four replication. The observed variables were dry matter consumption, average daily gain (ADG), and feed conversion. The results showed that the used of $15 \%$ C. calothyrsus and $15 \%$ Indigofera sp. was more efficient. The highest value of dry matter consumption $(P<0,05)$ and average daily gain $(P>0,05)$ obtained $P 5$ treatment, respectively $508,80 \mathrm{~g} /$ day and 45,36 $\mathrm{g} /$ day, while the lowest value offeed conversion $(P>0,05)$ obtained $P 0$ $(11,69)$ which was not significantly different with P5 $(11,75)$.
\end{abstract}

Keywords: Calliandra calothyrsus, Indigofera sp., weaned male sheep, the productivity of livestock

\section{PENDAHULUAN}

Domba Garut merupakan ruminansia kecil yang menjadi salah satu aset plasma nutfah asli Jawa Barat yang berpotensi sebagai ternak penghasil daging. Selain mudahnya manajemen pemeliharaan, target pasar daging domba telah tersedia. Keunggulan lainnya adalah cepat berkembang biak, beranak lebih dari satu ekor, dan dapat menghasilkan persentase daging yang lebih besar dibandingkan domba lainnya. Inounu et al. (2008) menyatakan bahwa Domba Garut dapat menghasilkan daging sekitar 50 persen dari berat badan, sedangkan untuk domba lain menghasilkan bobot potong sekitar 45-48\%.

Produktivitas ternak sebagian besar ditentukan oleh pakan, baik kualitas atau kuantitas. Sari et al. (2007) menjelaskan bahwa dalam meningkatkan kualitas perlu adanya sistem manajemen yang baik seperti pemberian pakan yang bermutu, perkandangan dan penanganan kesehatan terhadap ternak. Pakan dengan kualitas baik memiliki harga jual tinggi sehingga biaya produksi yang dikeluarkan akan semakin tinggi dan tidak ekonomis, terutama untuk peternak skala rakyat.

Kaliandra (Calliandra calothyrsus) dan Indigofera sp. merupakan hijauan leguminosa pohon yang dapat dijadikan alternatif pakan ternak dan dikenal sebagai bahan pakan sumber protein. Keduanya mampu mempertahankan kandungan protein yang tinggi karena mampu mengikat $\mathrm{N}$ dari atmosfir (Ginting, 2007). Kaliandra memiliki produksi BK yang tinggi yaitu 15-40 ton/ha/tahun (Tangendjaja et al., 1992), sedangkan Indigofera $s p$. sebesar 31,2 ton/ha/thn (Tarigan et al., 2010).

Keunggulan dari kedua tanaman tersebut diantaranya mudah didapat, harga murah, produksi tinggi, mampu mensuplai protein 
fermentable dan by pass, tahan kekeringan, serta dapat dijadikan pakan alternatif atau sebagai kombinasi pengganti konsentrat. Herdiawan et al. (2007) menyatakan bahwa kandungan protein kasar yang dimiliki leguminosa dapat dijadikan sebagai alternatif pengganti konsentrat yang harganya relatif murah, selain itu pemanfaatannya sebagai sumber protein dalam pakan ternak terutama pada musim kemarau dapat meningkatkan produktivitas ternak.

Kaliandra dan Indigofera sp. mengandung anti nutrisi tanin yang akan menjadi faktor pembatas karena sebagian besar dari zat tersebut bersifat racun. Kaliandra mengandung tanin sampai 11\% (Tangendjaja dan Wina, 1998), sedangkan Indigofera sp. hanya 0,08\% (Abdullah, 2010). Tanin bersifat mengikat protein yang nantinya ikatan protein-tanin akan lolos degradasi di dalam rumen (protein by-pass), namun tanin dapat menguntungkan apabila pakan yang diberikan tinggi kandungan proteinnya. Orskov (1981) menyebutkan bahwa untuk memperoleh produksi yang tinggi, khususnya pada fase tertentu, seperti masa pertumbuhan awal, bunting dan awal laktasi, maka pasokan protein mikroba belum mencukupi kebutuhan ternak. Oleh karena itu, diperlukan tambahan pasokan protein yang lolos fermentasi dalam rumen (protein by pass).

Sistem pemberian pakan secara co-feeding adalah salah satu upaya yang dapat dilakukan untuk mengoptimalkan penggunaan tanin yang merupakan sistem pemberian pakan dengan cara mencampurkan dua tanaman yang mengandung tanin tinggi dan rendah. Herdiawan et al. (2005) menjelaskan bahwa fungsi adanya sistem cofeeding adalah untuk mencegah sebagian protein terlarut agar tidak pecah di dalam rumen. Begitu pula menurut Wina et al. (2000) melaporkan bahwa sistem co-feeding yang diberikan pada sapi bunting tua yang dipelihara peternak di Jawa Timur dapat memberikan hasil yang positif terhadap performan, reproduksi, menekan kematian dan interval beranak dapat diperpendek.

Penelitian yang dilakukan bertujuan untuk mengkaji penggunaan Kaliandra (Calliandra calothyrsus), Indigofera sp. dan campurannya dalam ransum sebagai pengganti konsentrat terhadap produktivitas domba Garut jantan.

\section{MATERI DAN METODE}

\section{Materi}

Materi yang digunakan adalah hijauan Rumput Gajah Mini (Pennisetum purpureum cv. Mott), Kaliandra (Calliandra calothyrsus), dan Indigofera sp. yang diperoleh dari Balai Pengembangan Perbibitan Ternak Domba dan
Kambing, Margawati, Garut dan konsentrat yang diperoleh dari Koperasi Unit Desa (KUD) Tanjungsari. Hijauan sebelum diberikan dicacah dan dilayukan dahulu selama \pm 1 malam dan umur hijauan yang \pm 2-3 bulan, sedangkan objek yang digunakan adalah 24 ekor domba Garut jantan lepas sapih dengan umur 4-6 bulan.

\section{Metode}

Penelitian dilaksanakan di Balai Pengembangan Perbibitan Ternak Domba dan Kambing, Margawati, Garut, Jawa Barat selama 3 bulan dimana 2 minggu pertama adaptasi ransum dan 10 minggu selanjutnya perlakuan. Ransum yang dibuat memiliki kandungan Protein Kasar (PK) 12-16\% dan Total Digestible Nutrient (TDN) 57-60\%, dengan pemberian 3,5-4\% Bahan Kering (BK). Ransum diberikan tiga kali sehari yatu pagi, siang dan sore.

\section{Rancangan}

Penelitian menggunakan Rancangan Acak Lengkap, enam perlakuan dan empat ulangan, diuji menggunakan analisis sidik ragam (Analysis of Variance/ANOVA) dan uji lanjut Duncan Multiple Range Test (DMRT). Perlakuan terdiri dari : P0 (70\% Rumput $+30 \%$ Konsentrat); P1 $(70 \%$ Rumput $+15 \%$ Konsentrat $+15 \%$ Kaliandra); P2 (70\% Rumput $+15 \%$ Konsentrat + $15 \%$ Indigofera sp.); P3 (70\% Rumput $+30 \%$ Kaliandra); P4 (70\% Rumput + 30\% Indigofera sp.); P5 (70\% Rumput $+15 \%$ Kaliandra $+15 \%$ Indigofera sp.). Susunan dan kandungan nutrien ransum penelitian disajikan pada Tabel 1 .

\section{Variabel yang diamati}

Variabel yang diamati yaitu konsumsi bahan kering, pertambahan bobot badan harian dan konversi ransum.

\section{Konsumsi Bahan Kering (g/ekor/hari)}

$$
\mathrm{BK}=\mathrm{BK} \text { ransum yang diberikan }-\mathrm{BK} \text { sisa ransum }
$$

Pertambahan Bobot Badan Harian

$$
\text { PBBH }(\mathrm{g} / \text { ekor/hari })=\frac{\text { BB Akhir }- \text { BB Awal }}{\text { Lama Penelitianl }}
$$

(Supratman et al., 2016)

\section{Konversi ransum}

Konversi ransum $=\frac{\text { Konsumsi BK }(\mathrm{g} / \text { ekor.hari) }}{\mathrm{PBBH}(\mathrm{g} / \text { ekor/hari })}$

(Supratman et al., 2016) 


\section{HASIL DAN PEMBAHASAN}

\section{Konsumsi Bahan Kering Ransum}

Konsumsi bahan kering ransum bertujuan untuk memenuhi kebutuhan zat makanan dan menentukan produktivitas ternak. Berdasarkan Tabel 2 dapat diketahui bahwa rataan konsumsi ransum masing-masing perlakuan berkisar antara 429,92 g/hari sampai 508,80 g/hari. Rataan yang dihasilkan sejalan dengan penelitian Nuschati et al. (2010) yang menggunakan daun kering lamtoro, kaliandra dan gamal sebagai pakan domba dara ekor tipis (kira-kira berumur 8 bulan) dengan rataan konsumsi 489,7-535,7 g/hari.

Jumlah konsumsi bahan kering ransum hasil penelitian sebesar 3,8\% dari bobot badan, dimana konsumsi bahan kering tersebut masih berada pada kisaran normal kebutuhan bahan kering ternak ruminansia, yakni 3-4\% dari bobot badannya (Tillman et al., 1991). Konsumsi bahan kering ransum yang dihasilkan berbeda nyata $(\mathrm{P}<0,05)$ diantara perlakuan yang diujikan. Hal ini menunjukkan adanya perbedaan yang nyata konsumsi bahan kering dengan adanya pemberian tanaman Kaliandra dan Indigofera sp.

Jumlah konsumsi bahan kering akan menentukan banyaknya zat makanan yang masuk ke dalam tubuh ternak. Murtidjo (1993) menyebutkan bahwa pada batasan minimal, makanan bagi ternak domba berguna untuk menjaga keseimbangan jaringan tubuh dan membuat energi sehingga mampu melaksanakan peran dalam proses metabolisme.

Rataan konsumsi bahan kering ransum tertinggi dihasilkan oleh perlakuan P5 dengan adanya campuran kaliandra dan Indigofera sp., yaitu 508,80 g/hari. Perlakuan P5 berbeda nyata $(\mathrm{P}<0,05)$ dengan $\mathrm{P} 0, \mathrm{P} 2, \mathrm{P} 3$ dan $\mathrm{P} 4$ dengan hasil berturut-turut 471,19; 429,92; 467,01 dan 443,86 $\mathrm{g} /$ hari, serta berbeda tidak nyata $(\mathrm{P}>0,05)$ dengan P1 dengan hasil 489,47 dan g/hari. Perbedaan rataan yang dihasilkan diduga karena perlakuan yang diberikan memiliki palatabilitas atau tingkat kesukaan yang berbeda, sesuai pendapat Tillman et al. (1991) bahwa besarnya konsumsi pakan menunjukkan palatabilitas dan nilai kualitas pakan tersebut.

Tabel 1. Susunan dan Kandungan Nutrien Ransum Penelitian (Composition and Nutritional Content of Research Result)

\begin{tabular}{|c|c|c|c|c|c|c|}
\hline \multirow{2}{*}{$\begin{array}{l}\text { Bahan Pakan } \\
\qquad(\text { Feed })\end{array}$} & \multicolumn{6}{|c|}{$\begin{array}{l}\text { Persentase } \\
\text { (Percentage) }\end{array}$} \\
\hline & $\mathbf{P 0}$ & P1 & $\mathbf{P 2}$ & P3 & $\mathbf{P 4}$ & P5 \\
\hline & & & $\ldots \%$ & & & \\
\hline $\begin{array}{l}\text { Rumput Gajah Mini (Pennisetum } \\
\text { purpureum } \mathrm{cv} \text {. Mott) }\end{array}$ & 70,00 & 70,00 & 70,00 & 70,00 & 70,00 & 70,00 \\
\hline Kaliandra (C. calothyrsus) & 0,00 & 15,00 & 0,00 & 30,00 & 0,00 & 15,00 \\
\hline Indigofera falcate & 0,00 & 0,00 & 15,00 & 0,00 & 30,00 & 15,00 \\
\hline Konsentrat (Concentrate) & 30,00 & 15,00 & 15,00 & 0,00 & 0,00 & 0,00 \\
\hline Total (Total) & 100,00 & 100,00 & 100,00 & 100,00 & 100,00 & 100,00 \\
\hline \multicolumn{7}{|l|}{$\begin{array}{l}\text { Kandungan Nutrien } \\
\text { (Nutritional Content) }\end{array}$} \\
\hline Bahan Kering (DM) & 31,16 & 28,46 & 27,77 & 26,18 & 25,04 & 25,60 \\
\hline Protein Kasar (CP) & 12,00 & 13,06 & 13,57 & 15,22 & 15,82 & 15,52 \\
\hline Lemak Kasar (EE) & 3,95 & 2,54 & 2,48 & 1,36 & 1,40 & 1,38 \\
\hline Serat Kasar (CF) & 25,31 & 26,56 & 26,02 & 28,44 & 27,22 & 27,83 \\
\hline Abu $(A s h)$ & 15,06 & 13,55 & 14,19 & 11,74 & 12,91 & 12,33 \\
\hline BETN (Nitrogen Free Extract) & 43,80 & 43,79 & 43,95 & 42,65 & 43,24 & 42,94 \\
\hline TDN (Total Digestible Nutrient) & 60,00 & 58,00 & 58,00 & 57,03 & 57,01 & 57,02 \\
\hline
\end{tabular}

Keterangan : P0 (70\% Rumput + 30\% Konsentrat); P1 (70\% Rumput + 15\% Konsentrat + 15\% Kaliandra); P2 (70\% Rumput $+15 \%$ Konsentrat $+15 \%$ Indigofera sp. $)$; P3 (70\% Rumput $+30 \%$ Kaliandra); P4 (70\% Rumput $+30 \%$ Indigofera sp.); P5 (70\% Rumput + 15\% Kaliandra + $15 \%$ Indigofera sp.). 
Tabel 2. Nilai Rataan Hasil Penelitian (The Average Value of Research Result)

\begin{tabular}{|c|c|c|c|}
\hline $\begin{array}{l}\text { Perlakuan } \\
\text { (Treatment) }\end{array}$ & $\begin{array}{c}\text { Konsumsi Bahan Kering } \\
\text { (g/hari) } \\
\text { (Dry Matter Comsumption, } \\
\text { g/day) }\end{array}$ & $\begin{array}{c}\text { Pertambahan Bobot Badan } \\
\text { Harian (g/hari) } \\
\text { (Average Daily Gain, g/day) }\end{array}$ & $\begin{array}{l}\text { Konversi Ransum } \\
\text { (Feed Conversion) }\end{array}$ \\
\hline & \multicolumn{3}{|c|}{.....Rataan \pm SD $($ Average \pm Standar Deviation $)$} \\
\hline $\mathrm{P} 0$ & $471,19 \pm 12,38^{b}$ & $40,54 \pm 3,29^{a}$ & $11,69 \pm 0,84^{\mathrm{a}}$ \\
\hline $\mathrm{P} 1$ & $489,47 \pm 10,54^{\mathrm{c}}$ & $38,21 \pm 8,12^{\mathrm{a}}$ & $13,72 \pm 3,77^{\mathrm{a}}$ \\
\hline $\mathrm{P} 2$ & $429,92 \pm 3,21^{\mathrm{a}}$ & $36,07 \pm 3,73^{\mathrm{a}}$ & $12,06 \pm 1,42^{\mathrm{a}}$ \\
\hline P3 & $467,01 \pm 10,37^{\mathrm{b}}$ & $37,50 \pm 12,63^{\mathrm{a}}$ & $13,76 \pm 3,97^{\mathrm{a}}$ \\
\hline $\mathrm{P} 4$ & $443,86 \pm 7,91^{\mathrm{a}}$ & $33,21 \pm 5,16^{\mathrm{a}}$ & $13,64 \pm 1,77^{\mathrm{a}}$ \\
\hline P5 & $508,80 \pm 10,87^{\mathrm{c}}$ & $45,36 \pm 10,48^{a}$ & $11,75 \pm 2,38^{\mathrm{a}}$ \\
\hline
\end{tabular}

Keterangan : P0 (70\% Rumput + 30\% Konsentrat); P1 (70\% Rumput + 15\% Konsentrat + 15\% Kaliandra); P2 (70\% Rumput $+15 \%$ Konsentrat $+15 \%$ Indigofera sp.); P3 (70\% Rumput $+30 \%$ Kaliandra); P4 (70\% Rumput + 30\% Indigofera sp.); P5 (70\% Rumput + 15\% Kaliandra + $15 \%$ Indigofera sp.); Huruf Superskrip yang berbeda pada kolom yang sama menunjukkan pengaruh yang berbeda nyata $(\mathrm{P}<0,05)$.

Selain itu, perbedaan konsumsi ransum dapat dipengaruhi juga oleh suhu lingkungan di sekitar tempat penelitian. Pada suhu tinggi, ternak, akan mengurangi konsumsi ransum untuk menyeimbangkan suhu di dalam tubuhnya karena apabila konsumsi ransum tinggi, maka akan terjadi proses metabolisme di dalam tubuh dan suhu tubuh akan meningkat. Astuti et al. (2015) menyebutkan bahwa rendahnya konsumsi bahan kering ransum diduga karena kondisi lingkungan yang tinggi yang dapat mengakibatkan cekaman stres bagi ternak, sehingga berpengaruh menurukan konsumsi ransum dan meningkatkan konsumsi air minum.

Hal tersebut dijelaskan pula oleh Hill dan Eileen (2017) bahwa cuaca dapat mempengaruhi asupan ransum dan efisiensi ransum. Semakin meningkat suhu lingkungan, semakin menurun konsumsi ransum, namun menghasilkan kenaikan nilai konversi ransum.

\section{Pertambahan Bobot Badan Harian}

Pertambahan bobot badan harian $(\mathrm{PBBH})$ berguna untuk mengetahui laju pertumbuhan ternak. Tabel 2 dapat diketahui bahwa rataan pertambahan bobot badan masing-masing perlakuan berkisar antara 33,21 g/hari dan 45,26 g/hari. Rataan yang dihasilkan lebih tinggi dibandingkan penelitian Nuschati et al. (2010) yang menggunakan daun kering lamtoro, kaliandra dan gamal sebagai pakan domba dara dengan rataan PBBH 20,4-37,4 g/hari.

PBBH yang dihasilkan berbeda tidak nyata $(\mathrm{P}>0,05)$ diantara berbagai perlakuan. Hal ini menunjukkan tidak adanya perbedaan yang nyata pada PBBH dengan adanya pemberian tanaman Kaliandra dan Indigofera sp.
PBBH dari setiap perlakuan yang dihasilkan memiliki hasil yang sama, namun dilihat rataannya, perlakuan P5 memiliki hasil lebih tinggi. Hal ini diduga karena adanya campuran antara dua tanaman yang mengandung anti nutrisi tanin di dalam komposisi ransumnya, yakni kaliandra (11\% tanin) dan Indigofera $\mathrm{sp}$ (0,08\% tanin). Sistem pemberian pakan tersebut disebut dengan sistem co-feeding, yaitu mencampurkan dua tanaman dengan tanin tinggi dan rendah. Tanin dalam ransum pada batas tertentu dapat berdampak positif pada ternak, yakni dapat mengikat protein di dalam rumen sehingga lolos degradasi.

Konsumsi bahan kering dan palatabilitas ransum yang tinggi juga dapat mempengaruhi $\mathrm{PBBH}$, semakin banyak ransum yang dikonsumsi, maka semakin banyak zat-zat makanan yang dapat dicerna oleh ternak. Ransum yang memiliki kualitas dan palatabilitas yang tinggi dapat dengan cepat meningkatkan $\mathrm{PBBH}$ ternak dan laju pertumbuhan ternak yang cepat akan membutuhkan protein yang lebih tinggi didalam ransumnya.

Zat-zat makanan yang dikonsumsi akan digunakan untuk sistem metabolisme di dalam tubuhnya dan pada akhirnya akan dimanfaatkan oleh ternak untuk memenuhi kebutuhannya. Astuti et al. (2015) menjelaskan bahwa tingginya jumlah bahan kering ransum yang dikonsumsi akan meningkatkan jumlah asupan nutrisi yang diterima oleh ternak, semakin tinggi asupan nutrisi yang diterima oleh ternak maka nutrien yang masuk dalam tubuh semakin besar, sehingga mampu memenuhi kebutuhan hidup pokok

Suhu lingkungan yang berbeda juga dapat mempengaruhi PBBH. Menurut Astuti et al. 
(2015) bahwa suhu dan kelembaban udara yang lebih tinggi daripada comfort zone akan mengakibatkan ternak berusaha mengatur thermoregulasi tubuhnya agar tetap dalam kondisi normal. Ternak akan mengurangi konsumsi ransum apabila suhu tinggi atau panas sehingga akan berpengaruh terhadap zat makanan yang tersedia, yang pada akhirnya ketersediaan zat makanan untuk ternak menjadi berkurang.

\section{Konversi Ransum}

Konversi ransum merupakan gambaran dari jumlah ransum yang dikonsumsi dalam menghasilkan PBBH tertentu, semakin rendah angka konversi yang dihasilkan, menunjukkan ransum yang diberikan semakin efisien. Tabel 2 dapat diketahui bahwa rataan konversi ransum masing-masing perlakuan berkisar antara 11,69 sampai 13,76. Sama halnya dengan PBBH, konversi ransum yang dihasilkan berbeda tidak nyata $(\mathrm{P}>0,05)$ diantara berbagai perlakuan. Hal ini menunjukkan tidak adanya perbedaan yang nyata pada $\mathrm{PBBH}$ dengan adanya pemberian tanaman Kaliandra dan Indigofera sp.

Kualitas ransum yang baik akan menentukan tingkat konversi ransum yang dihasilkan. Semakin kecil nilai konversi ransum, maka semakin efisien ternak tersebut dalam memanfaatkan ransum yang dikonsumsi. Dijelaskan Martawidjaja (1998) bahwa kualitas ransum akan menentukan nilai konversi ransum. Penggunaan ransum akan semakin efisien bila jumlah ransum yang dikonsumsi minimal mampu menghasilkan pertambahan bobot badan yang tinggi.

Sama halnya dengan PBBH, konversi ransum dari setiap perlakuan memiliki hasil yang sama, akan tetapi dilihat dari nilai rataan, konversi ransum terendah dihasilkan oleh perlakuan $\mathrm{P} 0$ $(11,69)$ yang berbeda tidak nyata $(\mathrm{P}>0,05)$ dengan P5 (11,75), P2 (12,06), P4 (13,64), P1 (13,72) dan P3 $(13,76)$. Rataan yang dihasilkan tersebut lebih tinggi dibandingkan dengan penelitian Marhaeniyanto dan Susanti (2011) dengan menggunakan pakan basal jerami padi dan tambahan tanaman leguminosa gamal dan lamtoro yang diberikan pada domba jantan muda yang menghasilkan rataan sekitar 7,08-8,76, namun lebih rendah dibandingkan penelitian Rianto et al. (2006) yang menggunakan domba ekor tipis yang diberi pakan rumput dan ditambahkan dengan pollard dengan rataan konversi ransum sebesar 9,19-82,14.

Nilai konversi ransum dapat dipengaruhi oleh konsumsi bahan kering ransum dan PBBH. Konsumsi bahan kering yang rendah belum tentu menyebabkan nilai konversi menjadi rendah, atau sebaliknya, nilai konsumsi yang tinggi juga belum tentu menyebabkan nilai konversi menjadi tinggi. Nilai konsumsi bahan kering dipengaruhi oleh kualitas pakan, sedangkan PBBH ternak tergantung pada efisiensi pemanfaatan nutrien dalam proses metabolisme di dalam jaringan tubuh. Semakin baik kualitas pakan, semakin efisien penggunaannya oleh ternak, dan akibatnya akan diikuti oleh nilai PBBH yang makin tinggi (Marhaeniyanto dan Susanti, 2011).

\section{SIMPULAN}

Simpulan dari penelitian ini yaitu konsumsi $\mathrm{BK}$ ransum dan $\mathrm{PBBH}$ tertinggi dihasilkan oleh perlakuan pakan yang diberi campuran antara kaliandra dan Indigofera sp. sehingga campuran keduanya dapat dijadikan sebagai alternatif pakan pengganti konsentrat.

\section{DAFTAR PUSTAKA}

Abdullah, L. 2010. Herbage production and quality of shrub Indigofera treated by different concentration of foliar fertilizer. Media Peternakan 32:169-175.

Astuti, A., Erwanto, dan P. E. Santosa. 2015. Pengaruh cara pemberian konsentrathijauan terhadap respon fisiologis dan performa sapi peranakan simmental. JIPT 3(4):201-207.

Ginting, P. 2007. Sistem Pengelolaan Lingkungan dan Limbah Industri. CV. Yrama Widya. Bandung.

Herdiawan, I., A. Fanindi, dan A. Semali. 2005. Karakteristik dan pemanfaatan kaliandra (Calliandra calothyrsus). Lokakarya Nasional Tanaman Pakan Ternak: 141148.

Herdiawan, I., A. Semali dan Sajimin. 2007. Pengaruh pemberian tiga jenis leguminosa herba (Stylosanthes hammata, Clitoria ternate dan Lab-Lab purpureus) terhadap kualitas semen domba priangan. Seminar Nasional Teknologi Peternakan dan Veteriner: 496-501.

Hill, D. L. and W. Eileen. 2017. Weather influences feed intake and feed efficiency in a temperate climate. American Dairy Science Association. J. Dairy Sci. 100:118.

Inounu, I., D. Mauluddin dan Subandriyo. 2008. Karakteristik pertumbuhan domba Garut dan persilangannya. J. Ilmu Ternak Vet. 13(1):13-22.

Marhaeniyanto, E. dan S. Susanti. 2011. Strategi suplementasi leguminosa untuk 
meningkatkan penampilan domba. Buana Sains 11(1):7-16.

Martawidjaja. 1998. Pengaruh taraf pemberian konsentrat terhadap keragaan kambing kacang betina sapihan. Prosiding Seminar Nasional Peternakan dan Veteriner. Puslitbangnak. Balitbangtan. Deptan. Bogor, 5:6-8.

Murtidjo, B. 1993. Memelihara Kambing sebagai Ternak Potong dan Perah. Kanisius. Yogyakarta.

Nuschati, U., B. Utomo dan S. Prawirodigdo. 2010. Introduksi daun kering leguminosa pohon sebagai sumber protein dalam pakan komplit untuk ternak domba dara. Caraka Tani XXV (1):55-62.

Orskov, O. 1981. Protein Nutrition in Ruminant. Academic Press. New York.

Rianto, E., E. Haryono dan C. M. S. Lestari. 2006. Produktivitas domba ekor tipis jantan yang diberi pollard dengan aras berbeda. Seminar Nasional Teknologi Peternakan dan Veteriner: 431-439.

Sari, E. M., C. A. Fitri, dan D. Putra. 2007. Manajemen pemeliharaan domba lokal ditinjau dari aspek teknik pemeliharaan di Kabupaten Gayo Lues. J. Peternakan Indonesia 12(2): 88-93.

Supratman, H., H. Setiyatwan, D. C. Budinuryanto, A. Fitriani, dan D. Ramdani. 2016. Pengaruh imbangan hijauan dan konsentrat pakan komplit terhadap konsumsi, pertambahan bobot badan dan konversi pakan domba. J. Ilmu Ternak, 16 (1):31-35.

Tangendjaja, B., E. Wina, T. M. Ibrahim, dan B. Palmer. 1992. Kaliandra (Calliandra calothyrsus) dan manfaatnya. Balai Penelitian Ternak dan The Australian Centre For Institute Agricultural Research: 13-42.

Tangendjaja, B. dan E. Wina. 1998. Pengaruh transfer cairan rumen dari domba lokal ke domba merino terhadap kemampuan mencerna kaliandra. Prosiding Seminar Nasional Peternakan dan Veteriner: 448454.

Tarigan, A., L. Abdullah dan S. P. Ginting. 2010. Produksi dan komposisi nutrisi serta kecernaan in vitro Indigofera sp. pada interval dan tinggi pemotongan berbeda. $J$. Ilmu Ternak Vet, 15 (2): 188-195.

Wina, E., B. Tangendjaja, and B. Palmer. 2000. Free and bound tannin analysis in legume forage. In: Brooker, J. (ed). Tannins in Livestock and Human Nutrition. ACIAR Proceeding (92): 82-84.
Tillman, A. D., H. Hartadi, S. Reksohadiprodjo, S. Prawirokusumo dan S. Lebdosoekojo. 1991. Ilmu Makanan Ternak Dasar. Cetakan kelima. Universitas Gadjah Mada Press. Yogyakarta. 